\title{
Control of the Mexican bean weevil Zabrotes subfasciatus with kaolin
}

\author{
Controle do caruncho-do-feijão Zabrotes subfasciatus com caulim
}

\author{
Adriana Yatie Mikami' ${ }^{I}$ Aline Pissinati ${ }^{I}$ Dáfila Fagotti ${ }^{I}$ Ayres de Oliveira Menezes Júnior ${ }^{I I}$ \\ Maurício Ursi Ventura ${ }^{I^{*}}$
}

\begin{abstract}
The Mexican bean weevil Zabrotes subfasciatus (Coleoptera: Chrysomelidae: Bruchinae) is an important pest of stored beans in tropical regions. The efficiency of kaolin [with or without neem (Azadirachta indica) oil] and diatomaceous earth (DE) (standard treatment) was studied in laboratory aiming to obtain alternatives for chemical control of this insect. Insects were confined in plastic vials containing beans treated with kaolin (2, 4 and $8 \mathrm{~g} \mathrm{~kg}^{-1}$ ), kaolin + neem $\left[2 \mathrm{~g} \mathrm{~kg}^{-1}(5 \%\right.$ neem oil)], diatomaceous earth $\left(1 \mathrm{~g} \mathrm{~kg}^{-1}\right)$ and control. Mortality of adult insects, number of eggs and F1generation beetles emergency were assessed. Kaolin caused mortality of Z $\mathbf{Z}$. subfasciatus, however higher periods and doses than DE were necessary to promote high mortality (100\% or close). Kaolin treatments also affected female behavior because many eggs were placed in the vials walls. Number of emerged adults (F1) was similar between $D E$ and kaolin; hence, kaolin constitutes a promising tool to the management of $\mathbf{Z}$. subfasciatus. The mixture of kaolin and neem oil was not efficient in the control of $\mathbf{Z}$. subfasciatus.
\end{abstract}

Key words: bruchids, inert dusts, Phaseolus vulgaris.

\section{RESUMO}

O caruncho-do-feijão Zabrotes subfasciatus (Coleoptera: Chrysomelidae: Bruchinae) é uma importante praga de grãos de feijão armazenado nas regiões tropicais. A eficiência do caulim [com ou sem óleo de nim (Azadirachta indica)] e terra diatomácea (TD) (tratamento padrão) foi estudada em laboratório com o intuito de obter alternativas para o controle químico deste inseto. Insetos foram confinados em frascos de plástico com feijão tratado com caulim (2, 4 e $\left.8 \mathrm{~g} \mathrm{~kg}^{-1}\right)$, caulim $+\operatorname{nim}\left[2 \mathrm{~g} \mathrm{~kg}^{-1}(5 \%\right.$ óleo de nim $\left.)\right]$, terra diatomácea $\left(1 \mathrm{~g} \mathrm{~kg}^{-1}\right)$ e controle. Mortalidade de insetos adultos, número de ovos e emergência da geração $F 1$ foram avaliados. Caulim causou a mortalidade de Z. subfasciatus, porém foram necessários maiores períodos e doses que a TD para promover elevada mortalidade $(100 \%$ ou aproximadamente). Os tratamentos com caulim também afetaram o comportamento da fêmea, pois muitos ovos foram colocados nas paredes dos frascos. O número de adultos emergidos (F1) foi similar entre a TD e o caulim; portanto, caulim constitui uma ferramenta promissora para o manejo de Z. subfasciatus. A mistura de caulim e óleo de nim não foi eficiente no controle de $\mathbf{Z}$. subfasciatus.

Palavras-chave: bruquídeos, Phaseolus vulgaris, pós inertes.

\section{INTRODUCTION}

The weevil Zabrotes subfasciatus (Boheman, 1833) (Coleoptera: Crysomelidae: Bruchinae) is an important pest of beans (Phaseolus vulgaris $\mathrm{L}$.). This insect damages the stored legume seeds in tropical regions (SPERANDIO, 2001). Larvae develop in the cotyledons until reach adult stage, causing reduction of weight, nutritional quality (CREDLAND \& DENDY, 1992; GALLO et al., 2002), germination and vigor (HOHMANN \& CARVALHO, 1989) and also contributing to the development of fungi and mycotoxins in the grains. The quality of seeds is also reduced. Plants from seeds with one hole of $\boldsymbol{Z}$. subfasciatus presented a reduced number of seeds, weight of 100 seeds and yield; plants from seeds

\footnotetext{
'Programa de Pós-graduação em Agronomia, Centro de Ciências Agrárias, Universidade Estadual de Londrina (UEL), Londrina, PR, Brasil. IIDepartamento de Agronomia, UEL, CP 6001, 86051-970, Londrina PR, Brasil. E-mail: mventura@uel.br. Autor para correspondência.
} 
with four holes presented 3 and 2.5 times less germination and weight of 100 seeds, respectively, in comparison with the control (CHIPUNGAHELO et al., 2001).

Inert dust and botanical extracts have been studied as substitutes to chemical insecticides due to insect resistance, increasing costs and suitability for small farmer conditions (GARCIA et al., 2000; ALMEIDA et al., 2005). Neem plant (Azadirachta indica A. Juss) derivatives are referred as effective to more than 300 species of insects (SCHMUTTERER, 1990). OLIVEIRA \& VENDRAMIM (1999) found that the neem oil repelled $\boldsymbol{Z}$. subfasciatus weevils from beans. BARBOSA et al. (2002) obtained protection during 150 days using $3 \mathrm{~mL}$ of neem oil kg-1 of beans seed.

Diatomaceous earth (DE) also has been used to control insects in stored grains. This material acts physically on insects, destroying the cuticle by abrasion and absorbing lipids, causing insect death by desiccation (GOLOB, 1997). DE is the fossilized sediments of microscopic diatomaceous algae mainly composed of hydrated silica in the shape of disordered crystals (PINTO JÚNIOR et al., 2005) and may be associated with insecticides (BARROS, 1999; CERUTI \& LAZZARI, 2005); has no toxic effect for humans or animals (ATUI et al., 2003). LAZZARI (2005) obtained satisfactory control of $\boldsymbol{Z}$. subfasciatus using diatomaceous earth $\left(0.75\right.$ and $1.00 \mathrm{~g} \mathrm{~kg}^{-1}$ of beans) at different temperatures $\left(15,20,27\right.$ e $\left.30^{\circ} \mathrm{C}\right)$.

Kaolin is an aluminum silicate, nonabrasive dust that when activated by acid and heat treatments has a high specific surface that absorbs the wax in the epicuticle of insect pests of stored grains (EBELING, 1971). In addition, it has been referred as effective in the control of some plant pests such as aphids (COTTRELL et al., 2002), olive fruit flies (SAOUR \& MAKEE, 2004) and pear psyllids (GLENN et al., 1999). Thus, the efficiency of kaolin (with or without neem oil), compared with diatomaceous earth, on $\mathbf{Z}$. subfasciatus in common beans was studied in laboratory.

\section{MATERIAL AND METHODS}

Experiments were conducted in the Entomology Laboratory, Department of Agronomy, Universidade Estadual de Londrina, Londrina, PR, Brazil. A rearing facility of $\boldsymbol{Z}$. subfasciatus was maintained in the laboratory. Common bean cv. Carioca was used both in rearing and experiments. Treatments were kaolin (Protesyl ${ }^{\circledR}$ ) (Fertirico, Curitiba, PR, Brazil) (2, 4 and $\left.8 \mathrm{~g} \mathrm{~kg}^{-1}\right)$, kaolin + neem [2 $\mathrm{g} \mathrm{kg}^{-1}$ (5\% neem oil)]
(Fertirico, Curitiba, PR, Brazil); diatomaceous earth (DE) $\left(\right.$ KeepDry ${ }^{\circledR}$ ) (Vet Química, Campinas, SP, Brazil) (1g $\mathrm{kg}^{-1}$ ) and control. The dusts were placed in plastic bags containing the grains and mixed during two minutes. The grains $(30 \mathrm{~g})$ were put in $100 \mathrm{~mL}$ vials containing five holes of $0.5 \mathrm{~mm}$ in the cover. Five couples of $\mathbf{Z}$. subfasciatus beetles were placed in each vial. Vials were maintained in environmental chambers ( $\mathrm{T}$ $25 \pm 2^{\circ} \mathrm{C}$; RH 70+10\%; 12h Photophase).

Weevils' mortality was evaluated daily. Insects were considered dead when no movements were observed after be touched by a brush. After the assessment, died insects were recorded, sexed and discarded, and the alive insects were replaced in the vial. Eight days after experiment onset, all adults were removed and eggs quantified. The vials remained in the environmental chamber until total emergency of the F1 generation.

The completely randomized design was used. Proportion data (mortality) were transformed using arc sen (square root sen/100). ANOVA was performed on data and means compared using Tukey's test $(\mathrm{P}<0.05)$.

\section{RESULTS AND DISCUSSION}

In general, from second day after treatment, higher mortalities were found in the treatment with DE in which total mortality was observed in the third day for females and fourth day for males (Tables 1, 2). On the other hand, in the treatment using kaolin, $100 \%$ of mortality was observed in the fourth (4 and $8 \mathrm{~g} \mathrm{~kg}^{-1}$ ) and seventh $\left(2 \mathrm{~g} \mathrm{~kg}^{-1}\right)$ days for females; and 100 and $96 \%$ of mortality was found in the sixth $\left(2 \mathrm{~g} \mathrm{~kg}^{-1}\right)$ and eight ( 4 and $8 \mathrm{~g} \mathrm{~kg}^{-1}$ ) days for males, respectively. Higher doses of kaolin did not improve significantly the mortality.

In the treatment in which kaolin was mixed with neem oil, the efficiency was lower in the first assessments. Mortality was similar to the other treatments using kaolin just in the seventh and eight days for females and males, respectively (Table 1, 2). These results corroborate previous information about the relatively fast time of action of DE. Total mortality of Acanthoscelides obtectus (Coleoptera: Bruchinae) in common bean grains was referred at three and four days after treatment in the same dosage used in the present study (PINTO JÚNIOR et al., 2005; BAVARESCO, 2007).

The higher number of eggs in the grains was found on the control treatment (Table 3). In the treatment with kaolin + neem, values were intermediate. The lowest number of eggs was found 
Table 1 - Cumulative mortality(\%) of Zabrotes subfasciatus females in common beans grains treated with kaolin, kaolin + neem and diatomaceous earth in the laboratory $\left(25 \pm 2^{\circ} \mathrm{C}, 70 \% \mathrm{RH}\right.$; $12: 2 \mathrm{~L}$ : D).

\begin{tabular}{|c|c|c|c|c|c|c|c|c|}
\hline \multirow{2}{*}{ Treatments } & \multicolumn{8}{|c|}{--Cumulative mortality ${ }^{1}$ (Days after treatment) ---------------------------- } \\
\hline & 1 & 2 & 3 & 4 & 5 & 6 & 7 & 8 \\
\hline$\overline{\text { Kaolin }\left(2 \mathrm{~g} \mathrm{~kg}^{-1}\right)}$ & $16 \mathrm{C}$ ab & $28 \mathrm{C} \mathrm{bc}$ & $64 \mathrm{~B}$ bc & $84 \mathrm{AB}$ a & $92 \mathrm{~A}$ a & $96 \mathrm{~A}$ ab & $100 \mathrm{~A} \mathrm{a}$ & $100 \mathrm{~A} \mathrm{a}$ \\
\hline Kaolin $\left(4 \mathrm{~g} \mathrm{~kg}^{-1}\right)$ & $8 \mathrm{C} \mathrm{ab}$ & $44 \mathrm{~B}$ bc & $84 \mathrm{~A}$ ab & $100 \mathrm{~A} \mathrm{a}$ & $100 \mathrm{~A} \mathrm{a}$ & $100 \mathrm{~A} \mathrm{a}$ & $100 \mathrm{~A} \mathrm{a}$ & $100 \mathrm{~A} \mathrm{a}$ \\
\hline Kaolin $\left(8 \mathrm{~g} \mathrm{~kg}^{-1}\right)$ & $36 \mathrm{~B}$ a & $76 \mathrm{~A} \mathrm{a}$ & $92 \mathrm{~A} \mathrm{a}$ & $100 \mathrm{~A} \mathrm{a}$ & $100 \mathrm{~A} \mathrm{a}$ & $100 \mathrm{~A} \mathrm{a}$ & $100 \mathrm{~A} \mathrm{a}$ & $100 \mathrm{~A} \mathrm{a}$ \\
\hline Kaolin + neem [2 $\mathrm{g} \mathrm{kg}^{-1}(5 \%$ neem oil $\left.)\right]$ & $4 \mathrm{E} \mathrm{b}$ & $8 \mathrm{DE} \mathrm{c}$ & $40 \mathrm{CD}$ cd & $48 \mathrm{BC} \mathrm{b}$ & $64 \mathrm{ABC} b$ & $76 \mathrm{AB} \mathrm{b}$ & $84 \mathrm{~A} \mathrm{~b}$ & $92 \mathrm{~A} \mathrm{a}$ \\
\hline Diatomaceous earth $\left(1 \mathrm{~g} \mathrm{~kg}^{-1}\right)$ & $24 \mathrm{C}$ ab & $76 \mathrm{~B} \mathrm{a}$ & $100 \mathrm{~A} \mathrm{a}$ & $100 \mathrm{~A} \mathrm{a}$ & $100 \mathrm{~A} \mathrm{a}$ & $100 \mathrm{~A} \mathrm{a}$ & $100 \mathrm{~A} \mathrm{a}$ & $100 \mathrm{~A} \mathrm{a}$ \\
\hline Control & $4 \mathrm{C} \mathrm{b}$ & $16 \mathrm{BC}$ bc & $24 \mathrm{BC} d$ & $28 \mathrm{BC} \mathrm{b}$ & $36 \mathrm{AB} \mathrm{c}$ & $40 \mathrm{AB} \mathrm{c}$ & $56 \mathrm{~A} \mathrm{c}$ & $56 \mathrm{~A} \mathrm{~b}$ \\
\hline
\end{tabular}

${ }^{1}$ Means followed by the same letter did not differ using Tukey’s test $(\mathrm{P}<0.05)$ (capital letters in the lines and lower case in the columns).

in the higher doses of kaolin. Except for the control, females deposited eggs in the vials walls.

Higher number of emerged adults was observed in the control. In the kaolin + neem treatment values were intermediate (Table 3). DE and mostly kaolin probably changed the oviposition behavior because females placed their eggs in the walls of the vials. This behavior probably disabled larvae survival because when larvae hatch, they penetrate directly inside the grains without contact with the outside [CARVALHO \& ROSSETTO (1968) apud SPERANDIO (2001)]. Activated kaolin was also used for paddy rice treatment and suppressed progeny of some insect species for 250 days (PERMUAL \& PATOUREAL, 1992). Insecticidal proprieties of DE and activated kaolin are attributed mostly by the thin dust proprieties that absorbs the lipids of the insect cuticle what promotes its desiccation (EBELING, 1971; GOLOB, 1997). Although the kaolin formulation used in this study was not heat or acid activated, protection of the grains was found. Another probable explanation for this efficiency is the physical action of the dusts on the surface of the grains affecting beetles behavior. According to HEADLEE (1924), when beans are treated with some kinds of inert dusts, larvae slips have no adherence to on the grain surface and difficulties to drill into the bean. Kaolin (hydrated aluminum silicate) formulation, when applied to the plants, constitutes a protective barrier (Particle Film Technology) that acts by repellence or physical barrier which difficult movements, feeding and oviposition (GLENN \& PUTERKA, 2005). The results obtained in this study confirm for a pest of stored grains the previous results in which kaolin formulation reduced insect infestations in cultivated plants (EL-WAKEIL \& SALEH, 2007; COTTRELL et al., 2002). Apparently, the protective barrier was effective because, when bean grains were treated with kaolin, the majority of eggs were placed in the vials walls (Table 3 ).

Other inert dusts also have been proposed for the common bean beetles management. However, hydrated lime and mostly dolomitic lime and wood ash are used in higher concentration than the present study (6; 200 and $200 \mathrm{~g} \mathrm{~kg}^{-1}$, respectively) (BAVARESCO, 2007).

Although neem oil is reported as effective against Z. subfasciatus (BARBOSA et al., 2002; SILVA et al., 2007), antagonistic effects probably

Table 2 - Cumulative mortality (\%) of Zabrotes subfasciatus weevils males in common bean grains treated with kaolin, kaolin + neem and diatomaceous earth in the laboratory $\left(25 \pm 2^{\circ} \mathrm{C}, 70 \% \mathrm{RH} ; 12: 2 \mathrm{~L}\right.$ : D).

\begin{tabular}{|c|c|c|c|c|c|c|c|c|}
\hline \multirow{2}{*}{ Treatments } & \multicolumn{8}{|c|}{ 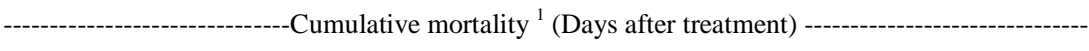 } \\
\hline & 1 & 2 & 3 & 4 & 5 & 6 & 7 & 8 \\
\hline Kaolin $\left(2 \mathrm{~g} \mathrm{~kg}^{-1}\right)$ & $8 \mathrm{D} \mathrm{a}$ & $32 \mathrm{CD}$ bc & $56 \mathrm{BC} \mathrm{b}$ & $84 \mathrm{AB}$ a & $96 \mathrm{~A} \mathrm{a}$ & $100 \mathrm{~A} \mathrm{a}$ & $100 \mathrm{~A} \mathrm{a}$ & $100 \mathrm{~A} \mathrm{a}$ \\
\hline Kaolin $\left(4 \mathrm{~g} \mathrm{~kg}^{-1}\right)$ & $4 \mathrm{D}$ a & $40 \mathrm{C} \mathrm{bc}$ & $72 \mathrm{~B}$ ab & $92 \mathrm{AB}$ a & $92 \mathrm{AB} a b$ & $92 \mathrm{AB}$ a & $92 \mathrm{AB}$ a & $96 \mathrm{~A} \mathrm{a}$ \\
\hline Kaolin $\left(8 \mathrm{~g} \mathrm{~kg}^{-1}\right)$ & $0 \mathrm{C} \mathrm{a}$ & $52 \mathrm{~B}$ ab & $92 \mathrm{~A} \mathrm{a}$ & $96 \mathrm{~A} \mathrm{a}$ & $96 \mathrm{~A} \mathrm{a}$ & $96 \mathrm{~A} \mathrm{a}$ & $96 \mathrm{~A} \mathrm{a}$ & $96 \mathrm{~A} \mathrm{a}$ \\
\hline Kaolin + neem $\left[2 \mathrm{~g} \mathrm{~kg}^{-1}(5 \%\right.$ neem oil $\left.)\right]$ & $4 \mathrm{D} \mathrm{a}$ & $12 \mathrm{D}$ bc & $24 \mathrm{CD}$ c & $48 \mathrm{BC} \mathrm{b}$ & $68 \mathrm{AB} b$ & $80 \mathrm{~A} \mathrm{a}$ & $96 \mathrm{~A} \mathrm{a}$ & $96 \mathrm{~A} \mathrm{a}$ \\
\hline Diatomaceous earth $\left(1 \mathrm{~g} \mathrm{~kg}^{-1}\right)$ & $24 \mathrm{~B} \mathrm{a}$ & $84 \mathrm{~A} \mathrm{a}$ & $96 \mathrm{~A} \mathrm{a}$ & $100 \mathrm{~A} \mathrm{a}$ & $100 \mathrm{~A} \mathrm{a}$ & $100 \mathrm{~A} \mathrm{a}$ & $100 \mathrm{~A} \mathrm{a}$ & $100 \mathrm{~A} \mathrm{a}$ \\
\hline Control & $4 \mathrm{~A} \mathrm{a}$ & $4 \mathrm{~A} \mathrm{C}$ & $4 \mathrm{Ac}$ & $8 \mathrm{~A} \mathrm{c}$ & $16 \mathrm{~A} \mathrm{c}$ & $20 \mathrm{~A} \mathrm{~b}$ & $32 \mathrm{~A} \mathrm{~b}$ & $40 \mathrm{~A} \mathrm{~b}$ \\
\hline
\end{tabular}

${ }^{1}$ Means followed by the same letter did not differ using Tukey’s test $(\mathrm{P}<0.05)$ (capital letters in the lines and lower case in the columns). 
Table 3 - Means number of eggs ( \pm SE) and emerged beetles of Zabrotes subfasciatus in common beans grains treated with kaolin, kaolin + neem and diatomaceous earth in laboratory $\left(25 \pm 2^{\circ} \mathrm{C}, 70 \% \mathrm{RH} ; 12: 2 \mathrm{~L}: \mathrm{D}\right)$.

\begin{tabular}{|c|c|c|c|c|c|c|}
\hline \multirow{2}{*}{ Treatments } & \multicolumn{3}{|c|}{-----------------Number of eggs ${ }^{1}---------------$} & \multicolumn{3}{|c|}{-----------------Emerged adults ${ }^{1}$. } \\
\hline & Grains & Vials & Total & Females & Males & Total \\
\hline Kaolin $\left(2 \mathrm{~g} \mathrm{~kg}^{-1}\right)$ & $10.4 \pm 2.4 \mathrm{bc}$ & $14.4 \pm 4.4 \mathrm{a}$ & $24.8 \pm 5.4 \mathrm{~b}$ & $3.6 \pm 0.9 \mathrm{bc}$ & $3.8 \pm 1.4 \mathrm{~b}$ & $7.4 \pm 1.9 \mathrm{~b}$ \\
\hline Kaolin $\left(4 \mathrm{~g} \mathrm{~kg}^{-1}\right)$ & $8.8 \pm 1.7$ bc & $11.4 \pm 2.4 \mathrm{a}$ & $20.2 \pm 2.6 b$ & $2.8 \pm 1.0 \mathrm{bc}$ & $3.4 \pm 1.1 \mathrm{~b}$ & $6.2 \pm 1.6 \mathrm{~b}$ \\
\hline Kaolin $\left(8 \mathrm{~g} \mathrm{~kg}^{-1}\right)$ & $0.8 \pm 0.8 \mathrm{c}$ & $10 \pm 6.5$ a & $10.2 \pm 6.4 \mathrm{~b}$ & $0.4 \pm 0.2 \mathrm{c}$ & $0.4 \pm 0.2 \mathrm{~b}$ & $0.8 \pm 0.4 \mathrm{~b}$ \\
\hline Kaolin + neem [2 $\mathrm{g} \mathrm{kg}^{-1}(5 \%$ neem oil $\left.)\right]$ & $26 \pm 4.1 \mathrm{~b}$ & $8.6 \pm 4.1 \mathrm{a}$ & $34.6 \pm 6.4 \mathrm{~b}$ & $9.8 \pm 1.5 \mathrm{ab}$ & $11 \pm 1.3 \mathrm{a}$ & $20.8 \pm 2.2 \mathrm{a}$ \\
\hline Diatomaceous earth & $7.8 \pm 2.7$ bc & $1.6 \pm 0.5 \mathrm{a}$ & $9.4 \pm 2.8 \mathrm{~b}$ & $4.4 \pm 1.8$ bc & $2.4 \pm 0.9 \mathrm{~b}$ & $6.8 \pm 2.6 b$ \\
\hline Control & $64.2 \pm 9.8 \mathrm{a}$ & $0 \pm 0.0 \mathrm{a}$ & $64.2 \pm 9.8 b$ & $15.4 \pm 3.8 \mathrm{a}$ & $16.8 \pm 3.0 \mathrm{a}$ & $32.2 \pm 6.2 \mathrm{a}$ \\
\hline
\end{tabular}

${ }^{1}$ Means followed by the same letter did not differ using Tukey’s test $(\mathrm{P}<0.05)$ (capital letters in the lines and lower case in the columns).

occurred when it was mixed with kaolin (Tables 1, 2 and 3). The oil may have affected the sorptive effect and the physical characteristics of kaolin and the protective layer would be negatively influenced. Further investigations using other neem derivatives (extracts or powders) can be conducted to test this hypothesis.

\section{CONCLUSION}

Kaolin treatment constitutes a suitable candidate for $\boldsymbol{Z}$. subfasciatus management because the F1 generation been similar to DE although higher periods and doses than DE is necessary to promote high mortality. The mixture of kaolin and neem oil is not efficient in the control of $\boldsymbol{Z}$. subfasciatus.

\section{REFERENCES}

ALMEIDA, F.A.C. et al. Efeitos de extratos alcoólicos de plantas sobre o caruncho do feijão vigna (Callosobruchus maculatus). Revista Brasileira de Engenharia Agrícola e Ambiental, v.9, n.4, p.585590, 2005. Available from: <http://www.scielo.br/ scielo.php? script=sci_arttext \& pid=S 1415 $43662005000400023 \& \operatorname{lng}=$ en $\& \mathrm{nrm}=$ iso $>$. Accessed: Dec 02, $2008 . \quad$ doi: 10.1590/S141543662005000400023 .

ATUI, M.B. et al. Avaliação de metodologia para a deteç̧ão de resíduos de terra diatomácea em grãos de trigo e farinha. Revista do Instituto Adolfo Lutz, v.62, n.1, p.11-16, 2003.

BARBOSA, F.R. et al. Controle do caruncho-do-feijoeiro Zabrotes subfasciatus com óleos vegetais, munha, materiais inertes e malathion. Pesquisa Agropecuária Brasileira, v.37, n.9, p.1213-1217, 2002. Available from: <http:// www.scielo.br/scielo.php?script=sci_arttext\&pid=S0100204X2002000900002\&lng=en\&nrm=iso>. Accessed: Apr 11, 2008. doi: 10.1590/S0100-204X2002000900002.

BARROS, A.S.R. Tratamento de sementes de milho com pó inerte. Revista Brasileira de Sementes, v.21, n.2, p.6469, 1999.
BAVARESCO, A. Avaliação de tratamentos alternativos para o controle do Acanthoscelides obtectus (Say) (Coleoptera: Bruchidae). Revista de Ciências Agroveterinárias, v.6, n.2, p.125-133, 2007.

CERUTI, F.C.; LAZZARI, S.M.N. Combination of diatomaceous earth and powder deltamethrin for insect control in stored corn. Revista Brasileira de Entomologia, v.49, n.4, p.580-583, 2005. Available from: <http://www.scielo.br/ scielo.php ? script = sci_arttext \& pid=S008556262005000400020\&lng=en\&nrm=iso>. Accessed: Jul 04, 2007. doi: $10.1590 /$ S0085-56262005000400020.

CHIPUNGAHELO, M.S. et al. The effect of sowing bruchid damaged bean (Phaseolus vulgaris L.) seeds on germination, plant development and yield. In: BEAN SEED WORKSHOP, 2001, Arusha, Tanzania. Available from: <<http:// sustainableseedsystems.wsu.edu/proceedings/Misangu.pdf $>$. Accessed: Oct 29, 2008.

COTTRELl, T.E et al. Particle film affects black pecan aphid (Homoptera: Aphididae) on pecan. Journal of Economic Entomology, v.95, n.4, p.782-788, 2002. Available from: <http://hdl.handle.net/10113/11297>. Accessed: May 09, 2009. doi: 10.1603/0022-0493-95.4.782.

CREDLAND, P.F.; DENDY, J. Intraspecific variation in bionomic characters of the Mexican bean weevil, Zabrotes subfasciatus. Entomologia Experimentalis et Applicata, v.65, n.1, p.39-47, 1992. Available from: <http:// Www.springerlink.com/content/g2717767u0t85442/>. Accessed: Jun 10, 2008. doi: 10.1007/BF00189715.

EBELING, W. Sorptive dusts for pest control. Annual Review of Entomology, v.16, p.123-158, 1971. Available from: http://arjournals.annualreviews.org/doi/pdf/10.1146/ annurev.en.16.010171.001011>. Accessed: Jun 12, 2008. doi: 10.1146/annurev.en.16.010171.001011.

EL-WAKEIL, N.E.; SALEH, S.A. Effects of neem and diatomaceous earth against Myzus persicae and associated predators in addition to indirect effects on artichoke growth and yield parameters. Research Journal of Agriculture and Biological Sciences, v.3, n.6, p.782-789, 2007. Available from: http://www.informaworld.com/smpp/ content $\sim$ content $=\mathrm{a} 790438666 \sim \mathrm{db}=\mathrm{all} \sim$ jumptype $=\mathrm{rss}$. Accessed: Jun 12, 2008. doi: 10.1080/ 03235400701650858 . 
GALLO, D. et al. Entomologia agrícola. Piracicaba: FEALQ, 2002. 920p.

GARCIA, J. et al. Eficiência de produtos alternativos no controle de Zabrotes subfasciatus, e seus efeitos sobre a qualidade das sementes de Phaseolus vulgaris. Pesquisa Agropecuária Tropical, v.30, n.2, p.39$42,2000$.

GLENN, D.M.; PUTERKA, G. Particle film technology: a new technology for agriculture. Horticultural Reviews, v.31, p.1-44, 2005. Available from: <http://www.wiley.com/ WileyCDA/WileyTitle/productCd-0471666947, descCdtableOfContents.html> Accessed: Dec 12, 2009.

GLENN, D.M. et al. Hydrophobic particle films: A new paradigm for suppression of arthropod pests and plant diseases. Journal of Economic Entomology, v.92, n.4, p.759-771, 1999

GOLOB, P. Current status and future perspectives for inert dusts for control of stored product insects. Journal of Stored Products Research, v.33, n.1, p.69-79, 1997. Available from: h t t p : / / w w w. s c i e n c e d i r e c t . c o m / science?_ob=ArticleURL\&_udi=B6T8Y-3RH0YH2$9 \&$ _user $=686187 \&$ _coverDate $=01 \% 2 \mathrm{~F} 31 \% 2 \mathrm{~F} 1997 \&$ \&doc $=1 \& \_f m t=h i g h \& \_o r i g=s e a r c h \& \_s o r t=d \& \_d o c a n c h o r=\& v i e w=c$ \&_searchStrId $=1322524215 \& \_$rerunOrigin $=$scholar.google\&_acct $=C$ 0000371998_version=18_urlVersion=0\&_userid=686187\& $\mathrm{md5}=44602 \mathrm{~d} 068 \mathrm{c} 236$ e2f806392061fad3da >. Accessed: Dec 12, 2009. doi:10.1016/ S0022-474X(96)00031-8.

HEADLEE, T.J. Certain dusts as agents for the protection of stored seeds from insect infestation. Journal of Economic Entomology, v.17, p.298-307, 1924.

HOHMANN, C.L.; CARVALHO, S.M. Pragas e seu controle. In: CARVALHO, M. et al. O feijão no Paraná. Londrina: IAPAR, 1989. p.217-246.

LAZZARI, F.N. Controle de Zabrotes subfasciatus (Boheman, 1833) (Coleoptera, Chrysomelidae, Bruchinae) e qualidade do feijão (Phaseolus vulgaris Linnaeus, 1753) tratado com terra de diatomácea. 2005. 69f. Dissertação (Mestrado em Ciências Biológicas) - Curso de Pós-graduação em Ciências Biológicas, Universidade Federal do Paraná, Curitiba, PR.

OLIVEIRA, J.V.; VENDRAMIM, J.D. Repelência de óleos essenciais e pós vegetais sobre adultos de Zabrotes subfasciatus (Boh.) (Coleoptera: Bruchidae) em sementes de feijoeiro.
Anais da Sociedade Entomológica do Brasil, v.28, n.3, p.549-555, 1999.

PERMUAL, D.; PATOUREL, G.N.J. Small bin trials to determine the effectiveness of acidactivated kaolin against four species of beetles infesting paddy under tropical storage conditions. Journal of Stored Products Research, v.28, p.193-199, 1992. Available from: http:// w w w s c i e n c e d i r e c t. c o m / science?_ob=ArticleURL\&_udi=B6T8Y-49N9236$2 N \&$ _user $=686187 \&$ _coverDate $=07 \% 2 F 31 \% 2 F 1992 \& \_$rdoc $=1 \&$ _ $\mathrm{fmt}=$ high\&_orig=search\&_sort $=\mathrm{d} \& \_$docanchor $=\&$ view $=\mathrm{c} \&$ searchStrId $=1322572985 \& \_$rerunOrigin $=$google\&_acct $=\mathrm{C} 00003$ 7199\&_version $=1 \&$ _urlVersion $=0$ \&_userid $=686187 \&$ md5 $=$ a06336396 b76577086df6755251ec5ea. Accessed: Dec 05, 2009. doi: $10.1016 / 0022-474 X(92) 90041-\mathrm{N}$

PINTO JÚNIOR, A.R. et al. Controle de Acanthoscelides obtectus (Coleoptera: Bruchidae) com diferentes doses de terra diatomácea (dióxido de sílica). Revista Acadêmica: ciências agrárias e ambientais, v.3, n.1, p.75-79, 2005.

SAOUR, G.; MAKEE, H. A kaolin-based particle film for suppression of the olive fruit fly Bactrocera oleae Gmelin (Dip., Tephritidae) in olive groves. Journal of Applied Entomology, v.128, p.28-31, 2004. Available from: <http:/ /www3.interscience.wiley.com/journal/118788835/abstract>. Accessed: Nov 20, 2009. doi: 10.1046/j.14390418.2003.00803.x.

SCHMUTTERER, H. Properties and potencial of natural pesticides from the neem tree, Azadirachta indica. Annual Review of Entomology, v.35, p.271-297, 1990. Available from: http://arjournals.annualreviews.org/doi/abs/10.1146/ annurev.en.35.010190.001415?journalCode=ento. Accessed: Sep 10, 2009. doi: 10.1146/annurev.en.35.010190.001415.

SILVA, J.P. et al. Antifeedant and allelopathic activities of the hydroalcoholic extract obtained from Neem (Azadirachta indica) leaves. Revista Brasileira de Farmacognosia, v.17, n.4, p.529-532, 2007. Available from: <http:// www.scielo.br/scielo.php?script=sci_arttext\&pid=S0102$695 X 2007000400009 \& \operatorname{lng}=$ en $\& n r m=i s o>$. Accessed: May 04, 2008. doi: 10.1590/S0102-695X2007000400009.

SPERANDIO, L.A.A. Alguns aspectos do comportamento de oviposição de fêmeas selvagens de Zabrotes subfasciatus (Coleoptera: Bruchidae) em condições de privações do hospedeiro. 2001. 76f. Dissertação (Mestrado em Ciências) - Curso de Pós-graduação em Entomologia, Universidade de São Paulo, SP. 